RASĀYAN J. Chem.

Vol. 13 | No. 1 |382 - 388| January - March | 2020 ISSN: 0974-1496 | e-ISSN: 0976-0083 | CODEN: RJCABP http://www.rasayanjournal.com http://www.rasayanjournal.co.in

\title{
PHYSICOCHEMICAL CHARACTERIZATION OF NATURAL KAOLIN FROM JABOI INDONESIA
}

\author{
R. Dewi ${ }^{1,3}$, H. Agusnar ${ }^{2, *}$, Z. Alfian ${ }^{2}$ and Tamrin ${ }^{2}$ \\ ${ }^{1}$ Postgraduate School, Department of Chemistry, Faculty of Mathematics and Natural Sciences, \\ Universitas Sumatera Utara, Medan, 20155, Indonesia \\ ${ }^{2}$ Department of Chemistry, Faculty of Mathematics and Natural Sciences, Universtitas Sumatera \\ Utara, Medan, 20155, Indonesia \\ ${ }^{3}$ Chemical Engineering Department, Lhokseumawe State Polytechnics, \\ Lhokseumawe, Indonesia \\ *E-mail: harryagusnar@yahoo.com
}

\begin{abstract}
In this study studied the physical and chemical properties of natural kaolin originating from Jaboi village, Sukajaya district, Sabang City, Aceh province, Indonesia. Natural kaolin deposits in this province are quite large and can be used as raw materials in various industries such as paints, ceramics, rubber medicines and others. Therefore, the study of the physical and chemical properties of natural kaolin through characteristic tests is very necessary so that its utilization in related industries can be optimized. The characteristic tests carried out include XRF, XRD, FTIR, SEM EDX and DSC/TGA where the results of the analysis obtained will be compared with the characteristics of commercial kaolin. Based on the XRF test, the main composition of Jaboi kaolin was obtained as follows: $\mathrm{SiO}_{2}$ (silica) and $\mathrm{Al}_{2} \mathrm{O}_{3}$ (alumina) respectively at $84.8 \%$ and $2.96 \%$, while the remaining impurities with concentrations below $1 \%$. XRD diffractograms identify quartz as the main mineral followed by kaolinite and cristobalite. These results are in accordance with the functional groups of FTIR spectra. The SEM test obtained the typical morphology of Jaboi kaolin, in the form of a heterogeneous group of layered hexagonal sheets and EDX results showing the composition of Jaboi kaolin elements consisting of $31.94 \%$ silicon, $1.33 \%$ aluminum $14.61 \%$ carbon and $50.78 \%$ oxygen. Based on the derivatogram in thermal analysis, there is no visible crystallization of the Jaboi kaolin. The results of all the characterizations of Jaboi kaolin show that Jaboi kaolin is very suitable for use in the refractory and ceramics industries.
\end{abstract}

Keywords: DSC/TGA, FTIR, Jaboi, Kaolin, Physicochemical, XRF, SEM EDX, XRD.

(C) RASĀYAN. All rights reserved

\section{INTRODUCTION}

Kaolin is composed of the mineral kaolinite as the main constituent which has the empirical formula $\mathrm{Al}_{2} \mathrm{Si}_{2} \mathrm{O}_{5}(\mathrm{OH})_{4}$ and is often called China clay. ${ }^{1-2}$ Natural kaolinite is a long-term chemical weathering product of aluminosilicate rocks. The process of forming kaolinite occurs due to weathering and alteration of hydrothermal processes in many igneous rocks containing feldspar, where aluminum silicate and feldspar potassium minerals are converted into kaolinite. ${ }^{3,4}$ Kaolinite has a 1:1 layer structure where each layer consists of tetrahedral sheets $\left(\mathrm{SiO}_{4}\right)$ and octahedral sheets containing $\mathrm{Al}^{3+}$ ions. ${ }^{5-6}$ The kaolinite particles have about 50 silicate layers, where the layers are bound together by the Van der Waals force and hydrogen bonds. ${ }^{7}$ As with other clay minerals, kaolinite having a particle size of the colloid group is $<2 \mu \mathrm{m}^{8}$. The chemical-physical properties of kaolin depend on the geological and climatic conditions in which kaolin deposits are formed. ${ }^{9-10}$

Jaboi kaolin as the name suggests originates from the Jaboi area of Sukajaya District, Sabang, Weh Island, Aceh Province. The kaolin deposit in this Aceh province is very large reaching 450 million tons and has not been utilized ${ }^{11}$. The location of kaolin is located at the foot of Jaboi mountain which is \pm 100 $\mathrm{m}$ from geothermal sources (Fig.-2). Research on the use of Jaboi kaolin has been done by several

Rasayan J. Chem., 13(1), 382-388(2020)

http://dx.doi.org/10.31788/RJC.2020.1315523

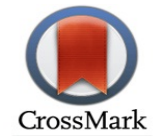


RASĀYAN J. Chem.

Vol. 13 | No. 1 |382 - 388| January - March | 2020

researchers ${ }^{11,12}$, but the studies were not studied the physical and chemical properties of Jaboi kaolin overall and utilization of natural kaolin is limited only as a source of alumina and as adsorbent. Researchers ${ }^{11}$ only mentioned the composition of Jaboi kaolin from XRF analysis at one sampling point and did not include the results of other characterizations. The same thing was also reported by other researchers ${ }^{12}$, where both researchers only reported the use of Jaboi kaolin with the results of chemical and physical characterization is very limited. Optimizing the use of Jaboi kaolin in the industry needs to be carried out research on the quality and characteristics of Jaboi kaolin to be suitable and can be used in certain industries.

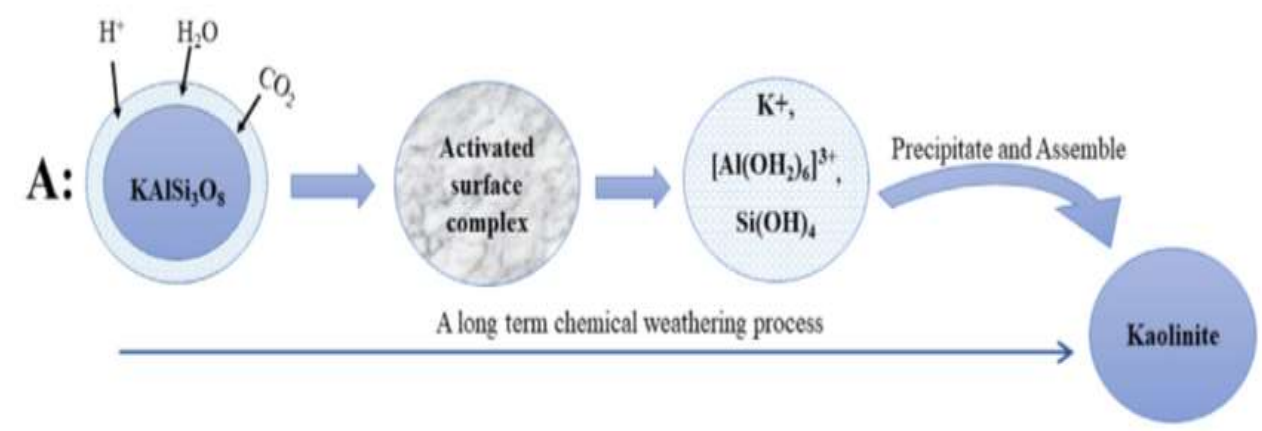

Fig.-1: Stages of Kaolinite Formation from Feldspar ${ }^{4}$

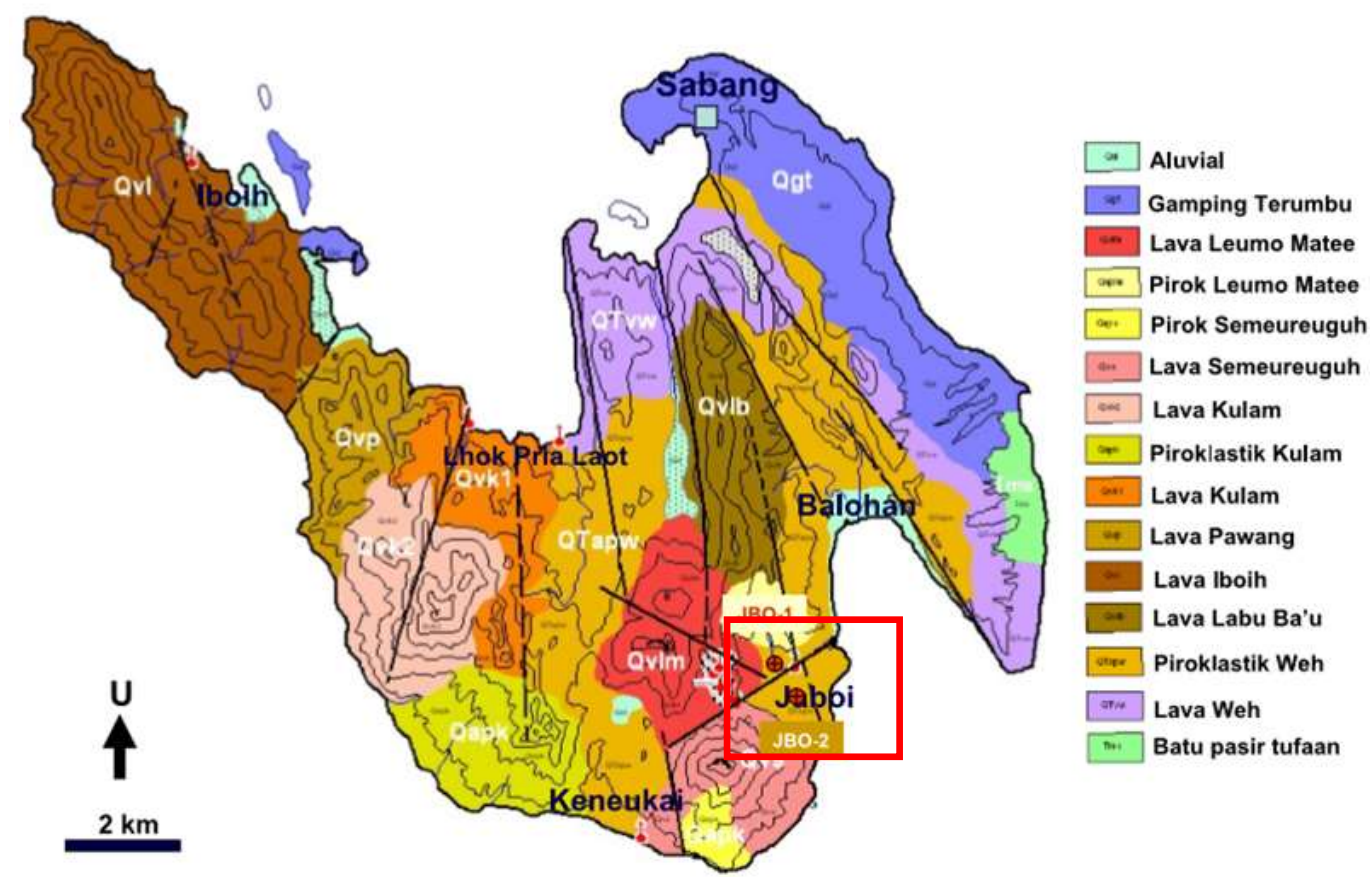

Fig.-2: Geological map of the Weh Island. ${ }^{13}$

This study aims to examine the physical-chemical properties and determine the Jaboi kaolin mineralogy in Suka Jaya sub-district in an effort to see the compatibility of this natural kaolin as a raw material in the industry.

\section{Material and Methods}

\section{EXPERIMENTAL}

In this study the sample to be tested was natural kaolin from the Jaboi area and as a comparison used commercial kaolin purchased from one of the chemical distributors in the city of Medan. The characterization test for kaolin was carried out using several instruments: XRF (PanAlytical Serie Axios, 
RASĀYAN J. Chem.

Vol. 13 | No. 1 |382 - 388| January - March | 2020

Philips), XRD (Shimadzu XRD-6000), FTIR (Shidmazu IR Prestige-21), SEM-EDX (Carl Zeiss-Bruker, Type EVO MA10) and DSC / TGA (Shidmazu, DSC/TGA- 60).

\section{General Procedure}

The natural kaolin used came from the Jaboi area, Sukajaya sub-district, Sabang city, Aceh Province, Indonesia. This area is located on $95^{\circ} 12^{\prime} 00^{\prime \prime} \mathrm{E}-95^{\circ} 23^{\prime} 00^{\prime} \mathrm{E}$ and $05^{\circ} 46^{\prime} 00^{\prime \prime} \mathrm{N}-05^{\circ} 55^{\prime} 00^{\prime \prime} \mathrm{N}$, about $15 \mathrm{~km}$ south of Sabang city. Kaolin is taken at three sampling points with a depth of $25 \mathrm{~cm}$ below the soil surface. Kaolin is crushed and sieved to obtain a uniform size using a 100 mesh sieve and dried in an oven at $105^{\circ} \mathrm{C}$ for about 2 hours. Commercial kaolin that is used as a comparison is also carried out the same treatment. Furthermore, the characterization of Jaboi kaolin is done using XRF, XRD, FTIR, SEM $\mathrm{EDX}$ and DSC / TGA.

\section{Detection Method}

Jaboi kaolin and commercial kaolin compositions were determined using X-ray fluorescence (XRF) machines (PanAlytical Serie Axios, Philips). X-ray diffraction (XRD (Shimadzu XRD-6000) was conducted in ambient conditions with $(\mathrm{Cu} \mathrm{K \alpha})$ diffractometer to determine the constituent minerals of Jaboi kaolin, the scan speed of 2 degree min-1, step size of $0.02^{\circ}$, and $2 \theta$ from $7^{\circ}$ to $70^{\circ}$. The infrared spectrum of absorption for kaolin was measured using Fourier transform infrared spectroscopy (FTIR Shidmazu IR Prestige-21) at wavelengths range of 4000-500 $\mathrm{cm}^{-1}$. The morphology and elemental composition of the Jaboi kaolin were observed from SEM EDX (Carl Zeiss-Bruker, EVO MA10 Type) at an acceleration voltage of $15 \mathrm{kV}$. Magnification of 1,000 images was chosen to reveal the kaolinite layer. The samples will be checked initially coated surface using gold plating by sputtering to improve conductivity. Thermal analysis was carried out using DSC / TGA (Shidmazu, DSC/TGA- 60). Samples used as much as $5 \mathrm{mg}$ with a flow rate of $20 \mathrm{ml} / \mathrm{min}$ at a temperature range of $20^{\circ} \mathrm{C}-600^{\circ} \mathrm{C}$.

\section{X-ray Fluorescence Analysis of Jaboi Kaolin}

\section{RESULTS AND DISCUSSION}

Jaboi kaolin content analyzed using XRF tool and the results obtained are shown in Table-1. Commercial kaolin is used as a comparison. XRF analysis results showed that Jaboi kaolin contained $\mathrm{SiO}_{2}$ and $\mathrm{Al}_{2} \mathrm{O}_{3}$ of $84.8 \%$ and $2.96 \%$, while other impurities composition such as $\mathrm{K}_{2} \mathrm{O}, \mathrm{Fe}_{2} \mathrm{O}_{3}, \mathrm{TiO}_{2}, \mathrm{MgO}, \mathrm{SO}_{3}$ were under $1 \%$. Based on the data obtained shows a very high silica content while the alumina content is very low. This is caused by the presence of Jaboi kaolin in the volcano area which affects the silica content to be so large. When compared with the commercial kaolin composition, there were differences in the levels of silica and alumina where the composition of commercial kaolin $\mathrm{SiO}_{2}$ and $\mathrm{Al}_{2} \mathrm{O}_{3}$ were $45.98 \%$ and $40.26 \%$ respectively.

Table-1: Composition of Jaboi Kaolin vs Commercial Kaolin Based on XRF Analysis.

\begin{tabular}{l|l|l|l|l|l|c}
\hline \multirow{2}{*}{ Compound } & \multirow{2}{*}{ Unit } & \multicolumn{3}{|l|}{ Three Sampling Points } & \multirow{2}{*}{ Average } & Commercial \\
\cline { 3 - 5 } & & Point 1 & Point 2 & Point 3 & & 12.00 \\
\hline Loss on ignition & $\%$ & 10.68 & 9.72 & 12.6 & 11.000 & 14.12 \\
\hline $\mathrm{SiO}_{2}$ & $\%$ & 82.75 & 87.75 & 83.9 & 84.800 & 45.98 \\
\hline $\mathrm{Al}_{2} \mathrm{O}_{3}$ & $\%$ & 3.46 & 2.35 & 3.07 & 2.960 & 40.26 \\
\hline $\mathrm{Fe}_{2} \mathrm{O}_{3}$ & $\%$ & 1.39 & 0.26 & 0.26 & 0.637 & 0.78 \\
\hline $\mathrm{MgO}$ & $\%$ & 0.34 & 0.18 & 0.16 & 0.227 & 0.04 \\
\hline $\mathrm{SO}_{3}$ & $\%$ & 0.04 & 0.04 & 0.00 & 0.027 & 0.09 \\
\hline $\mathrm{K}_{2} \mathrm{O}$ & $\%$ & 1.78 & 0.13 & 0.22 & 0.710 & 0.75 \\
\hline $\mathrm{CaO}$ & $\%$ & 0.11 & 0.13 & 0.14 & 0.127 & 0.00 \\
\hline $\mathrm{Na}_{2} \mathrm{O}$ & $\%$ & 0.13 & 0.05 & 0.05 & 0.077 & 0.03 \\
\hline $\mathrm{P}_{2} \mathrm{O}_{5}$ & $\%$ & 0.03 & 0.02 & 0.03 & 0.027 & 0.033 \\
\hline $\mathrm{TiO}_{2}$ & $\%$ & 0.55 & 1.029 & 0.978 & 0.852 & 0.321 \\
\hline $\mathrm{Mn}_{2} \mathrm{O}_{3}$ & $\%$ & 0.02 & 0.006 & 0.007 & 0.011 & 0.009 \\
\hline $\mathrm{Cr}_{2} \mathrm{O}_{3}$ & $\%$ & 0.01 & 0.002 & 0.005 & 0.006 & 0.003 \\
\hline
\end{tabular}


RASĀYAN J. Chem.

Vol. 13 | No. 1 |382 - 388| January - March | 2020

Natural kaolin research was also carried out by several researchers ${ }^{14,15}$, such as natural kaolin in Balikesir region ${ }^{14}$, Turkey having silica levels of $63.11 \%$ and alumina levels of $25.43 \%$. While kaolin originating from Tabarka, Tunisia is reported to have silica and alumina levels of $53.2 \%$ and $27.3 \%$, respectively. ${ }^{15}$ Other research ${ }^{16}$ reported the results of the analysis obtained kaolin containing silica and alumina amounted to $60.54 \%$ and $22.55 \%$. The difference in silica and alumina levels (mineralogical composition) of natural kaolin is strongly influenced by the geology of the kaolin deposit. Kaolin deposits can be sedimentary, residual, or hydrothermal and in almost every example kaolin has different properties and must, therefore, be fully tested and evaluated to determine their utilization. ${ }^{17}$

\section{Fourier Transform Infrared Analysis of Jaboi Kaolin}

The spectra of Jaboi kaolin and commercial kaolin are shown in Fig.-3. The spectral analysis will help in the identification of various forms of minerals present in the clay. The presence of kaolinite minerals can be detected by differences in position and relative intensity of $\mathrm{OH}$ stretching and bending band in the IR spectrum. ${ }^{6}$ Jaboi kaolin shows absorption bands at wavelengths of $3600-3700 \mathrm{~cm}^{-1}$, uptake at 3620 and $3606 \mathrm{~cm}^{-1}$ due to stretching vibrations of hydroxyl groups. ${ }^{18}$ The bands at 3620 and $3606 \mathrm{~cm}^{-1}$ are hydroxyl groups on the surface of the octahedral alumina layer which are connected to oxygen atoms from the adjacent silica tetrahedral layer. ${ }^{6,24,19}$

The presence of kaolinite is also clearly visible at $3620 \mathrm{~cm}^{-1}$. Jaboi kaolin spectra show sharp absorption in the regions of 1606,1822 and $1938 \mathrm{~cm}^{-1}$ which is the absorption of the bend-OH vibration trapped in the crystal lattice. Si-O stretching vibration which is a typical absorption of kaolinite minerals is shown in $1118,1002,898$ and $746 \mathrm{~cm}^{-1} .19$

Spectra in the range of 779 to $797 \mathrm{~cm}^{-1} 1$ indicate the presence of cristobalite minerals while quartz is predicted at spectra of $628 \mathrm{~cm}^{-1} 20-21$. The FTIR spectra of Jaboi kaolin when compared to commercial kaolin there are close absorption peaks, both for the hydroxyl group, the kaolinite, quarsa and cristobalite minerals.

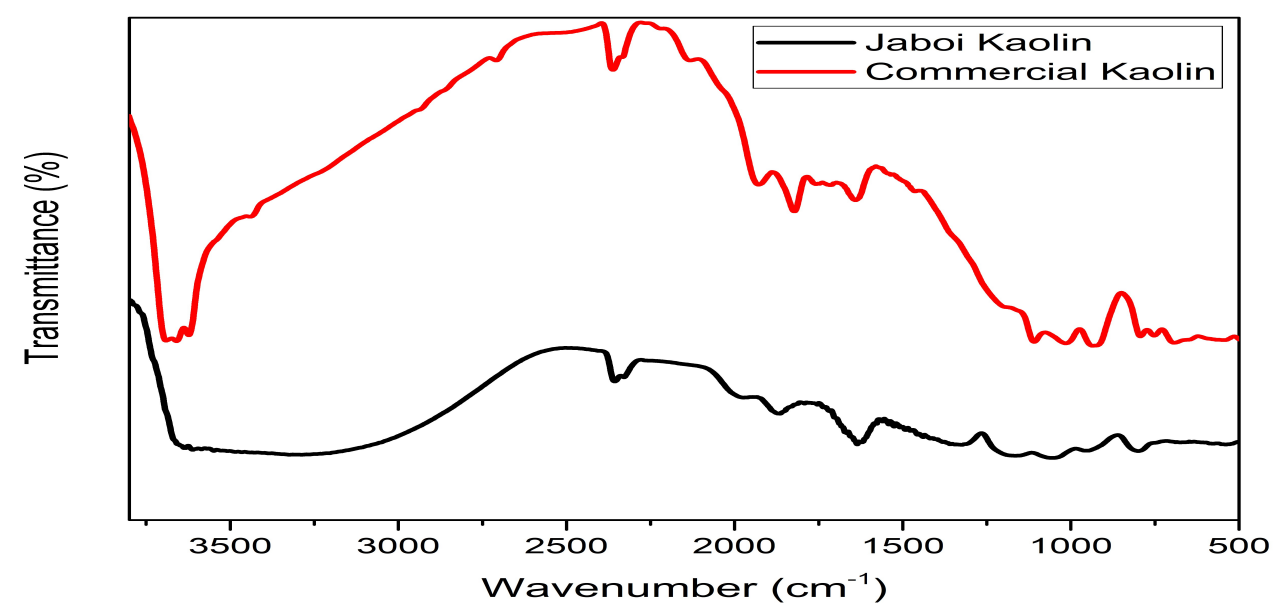

Fig.-3: Jaboi Kaolin and Commercial Kaolin Infrared Spectra

\section{X-ray Diffraction Analysis of Jaboi Kaolin}

The XRD patterns of the Jaboi kaolin and commercial kaolin are given in Fig.-4. The diffraction peaks of each clay mineral are typical, the diffraction angle $2 \theta$ is related to the crystal lattice plane of the analyzed mineral.

Identification of the constituent components of kaolin minerals is done by comparing the peak position of

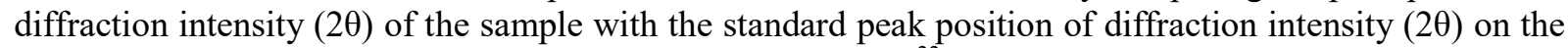
Joint Committee for Powder Diffraction Standards (JCPDS). ${ }^{22}$ Based on XRD analysis results, it can be seen that Jaboi kaolin consists of kaolinite minerals shown at $2 \theta\left({ }^{\circ}\right)=21.52$ with $\mathrm{d}$ spacing $4.125^{23}$, quartz at $2 \theta\left({ }^{\circ}\right)=21.82$ with $d$ spacing 4.068 and cristobalite at $2 \theta\left({ }^{\circ}\right)=35.9$ with $d$ spacing $2.49 .{ }^{24}$ From the diffraction intensity of the three minerals, quartz is the mineral with the largest composition, followed by the minerals kaolinite and cristobalite. This is according to the results of FTIR spectra which indicate the 
RASĀYAN J. Chem.

Vol. 13 | No. 1 |382 - 388| January - March | 2020

presence of the three minerals. Commercial kaolin contains kaolinite as the main constituent mineral at $2 \theta$ $\left({ }^{\circ}\right)=12.26$ and 38.35 with $\mathrm{d}$ spacing 7.21 and $2.345 .{ }^{24}$ While the quartz minerals as impurities are found at $2 \theta\left({ }^{\circ}\right)=24.81$ with $d$ spacing 3.585 .

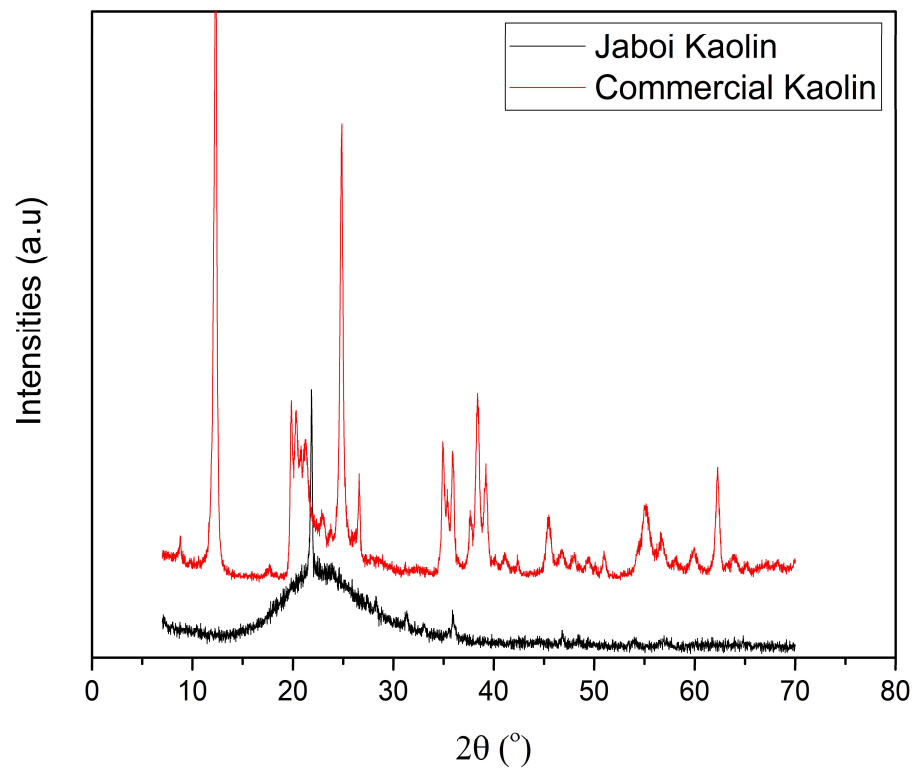

Fig.-4: Diffraction Pattern of Jaboi Kaolin and Commercial Kaolin

\section{Surface Morphology of Jaboi Kaolin}

SEM image (Fig.-5a and Fig.-5b) shows the morphology of Jaboi kaolin and commercial kaolin. Based on the results of the micrographs show that hexagonal platelets of the mineral kaolinite with a nonuniform size, in addition to the presence of quartz and cristobalite impurities. ${ }^{19,22,25}$ Jaboi kaolin has a pore size in the range of 2.145-6.701 $\mu \mathrm{m}$. Impurity minerals, both quartz and cristobalite, are seen in the form of chunks that cover the mineral kaolinite. Commercial kaolin micrograph results show hexagonal platelet with a smaller and uniform size. This indicates that impurities in commercial kaolin are relatively small. This result is supported by the measurement of the pore diameter obtained smaller than the pore diameter of Jaboi kaolin, which is in the range of $1.117-4.020 \mu \mathrm{m}$. The EDX results showed that the composition of the Jaboi kaolin element consisted of $31.94 \%$ silicon, $1.33 \%$ aluminum, $14.61 \%$ carbon and $50.78 \%$ oxygen. While from the results of EDX commercial kaolin obtained $16.27 \%$ silicon, $16.2 \%$ aluminum, $2.44 \%$ carbon and $46.46 \%$ oxygen. The EDX results of the two types of kaolin are in accordance with $\mathrm{XRF}$ analysis as shown in Table-1.
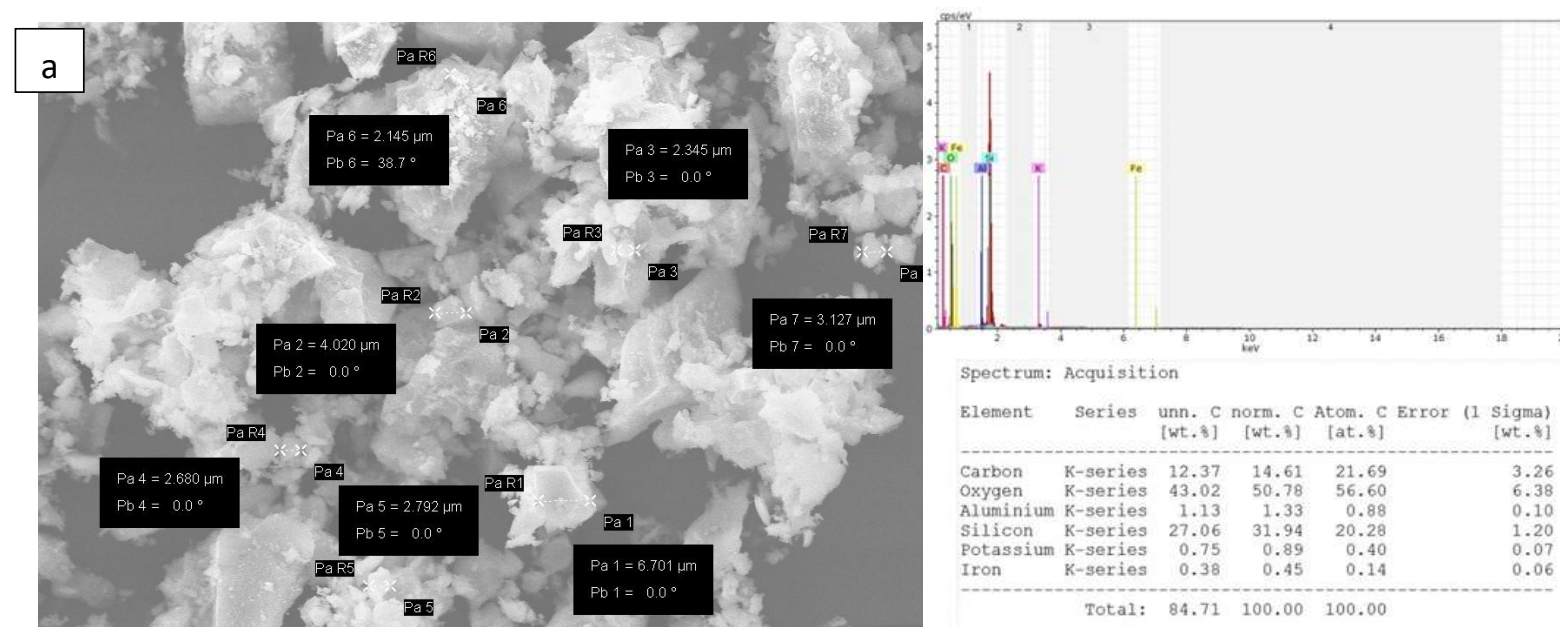

Fig.-5a: SEM EDX Jaboi Kaolin 
RASĀYAN J. Chem.

Vol. 13 | No. 1 |382 - 388| January - March | 2020

\section{DSC/TGA Analysis}

Kaolin phase transformation in the temperature range of $20^{\circ} \mathrm{C}-600^{\circ} \mathrm{C}$ was studied using differential thermal analysis. Jaboi kaolin derivatogram is shown in Fig.-6. The DSC curve shows an endothermic effect at $20^{\circ} \mathrm{C}-40^{\circ} \mathrm{C}$, a sharp peak (endothermic peak) that occurs due to the removal of hygroscopic water or evaporation of water.
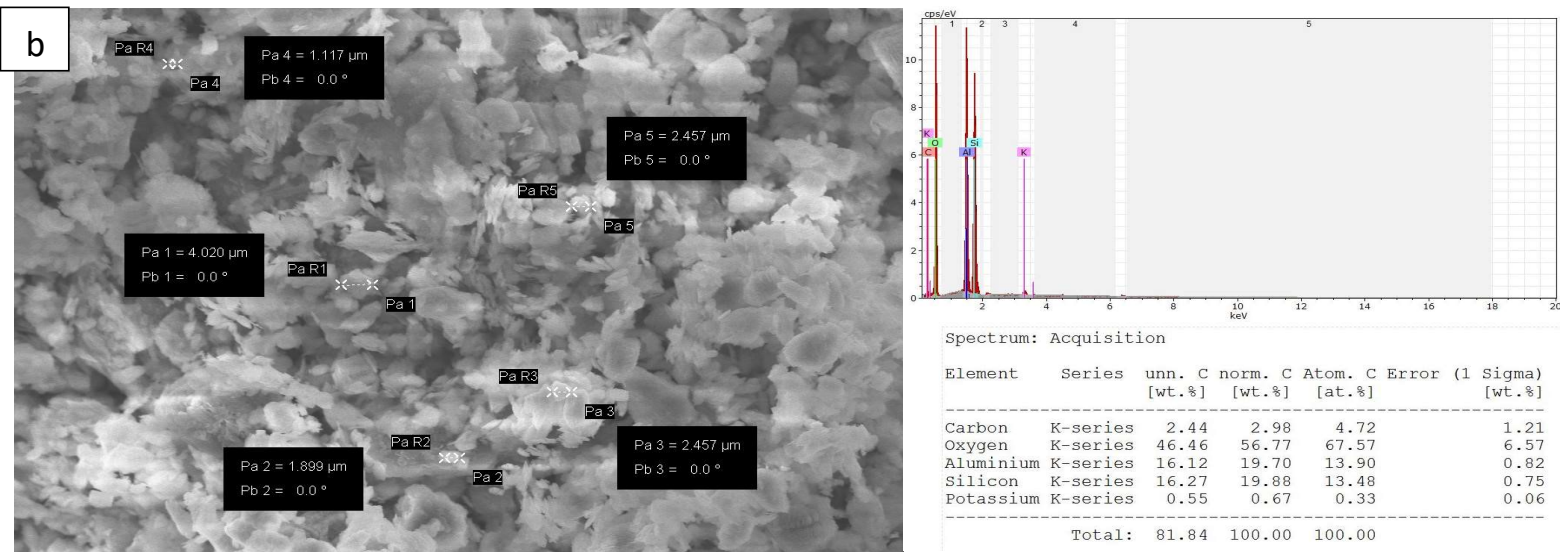

Fig.-5b: SEM EDX Commercial Kaolin

The endothermic curve is quite sharp and wide there is also at a temperature of $90^{\circ} \mathrm{C}-200^{\circ} \mathrm{C}$ caused by the release of bonds of water molecules. This evaporation process requires heat $\Delta \mathrm{H}=169.74 \mathrm{~J} / \mathrm{g}$ or $\Delta \mathrm{H}=$ $40.55 \mathrm{cal} / \mathrm{g}$. Based on the derivatogram, there is no visible crystallization of the Jaboi kaolin. From the results of the thermal gravimetric analysis (TGA) analysis, kaolin heated from a temperature of $20{ }^{\circ} \mathrm{C}$ $600^{\circ} \mathrm{C}$ changes in mass by $6-8 \%{ }^{26}$
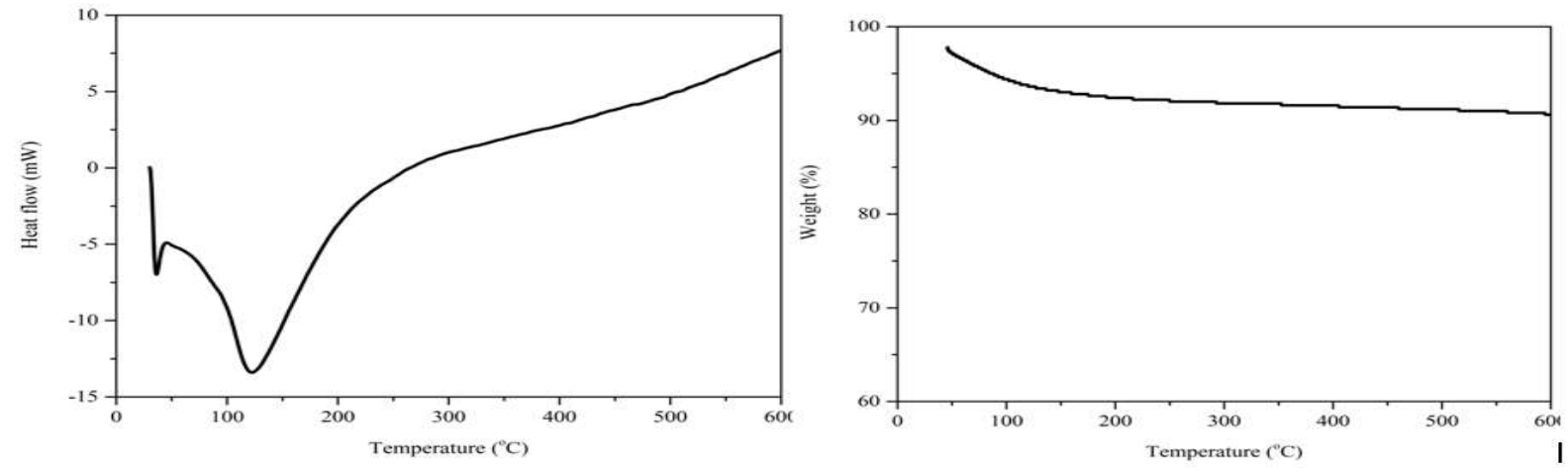

Fig.-6: DSC/TGA Curves of Jaboi Kaolin

\section{CONCLUSION}

This study studied the physical and chemical properties of Jaboi kaolin through characteristic tests using XRF, FTIR, XRD, SEM-EDX and DSC/TGA. Based on the XRF test, the main composition of Jaboi kaolin was obtained as follows: $\mathrm{SiO}_{2}$ (silica) and $\mathrm{Al}_{2} \mathrm{O}_{3}$ (alumina) respectively at $84.8 \%$ and $2.96 \%$, while the remaining impurities with concentrations below $1 \%$. The results of FTIR spectra and diffraction intensity using XRD can be seen that the mineral constituents of Jaboi kaolin are quartz, kaolinite and cristobalite. Quartz is the main mineral, followed by kaolinite and cristobalite. The SEM test obtained the typical morphology of Jaboi kaolin, in the form of a heterogeneous group of layered hexagonal sheets with pore sizes in the range $2.145-6.701 \mu \mathrm{m}$. EDX results showing the composition of Jaboi kaolin elements consisting of $31.94 \%$ silicon, $1.33 \%$ aluminum, $14.61 \%$ carbon and $50.78 \%$ oxygen. The results of EDX Jaboi kaolin are supported by XRF, FTIR and XRD analysis results. Based on the derivatogram in thermal analysis, there is no visible crystallization of the Jaboi kaolin. Jaboi kaolin characterization results indicate that kaolin is very suitable for use as a raw material in the refractory and ceramics industries. 
RASĀYAN J. Chem.

Vol. 13 | No. 1 |382 - 388| January - March | 2020

\section{ACKNOWLEDGMENT}

This research was supported by the Ministry of Research, Technology and Higher Education, the Republic of Indonesia through BPPDN scholarship funding.

\section{REFERENCES}

1. C.O. Mgbemena, N.O. Ibekwe, R. Sukumar and A.R.R. Menon, Journal of King Saud UniversityScience, 25(2), 149(2013), DOI: 10.1016/j.jksus.2012.11.004

2. S.Yahaya, S.S. Jikan, N.A. Badarulzaman and A.D. Adamu, Traektoriâ Nauki= Path of Science, 3(9), 4001(2017), DOI: 10.22178/pos.26-6

3. B.J. Saikia, and G. Parthasarathy, Journal of Modern Physics, 1(04), 206(2010) DOI: $10.4236 / j m p .2010 .14031$

4. J. Yuan, J. Yang, H. Ma, S. Su, Q. Chang and S. Komarneni, Ceramics International, 44(13), 15611(2018), DOI:10.1016/j.ceramint.2018.05.227

5. K.G. Bhattacharyya and S.S. Gupta, Advances in Colloid and Interface Science, 140(2), 114 (2008), DOI: $10.1016 /$ j.cis.2007.12.008

6. M. Diko, G. Ekosse and J. Ogola, Acta Geodyn Geomater, 13(2), 149(2016), DOI: 10.13168/AGG.2015.0052

7. F. Rao, F.J. Ramirez-Acosta, R.J. Sanchez-Leija, S. Song and A. Lopez-Valdivieso, Applied Clay Science, 51(1-2), 38(2011), DOI:10.1016/j.clay.2010.10.023

8. F. Bergaya and G. Lagaly, Developments in clay science 1, 11(2006), DOI:10.1016/S15724352(05)01001-9

9. S.K. Hubadillah, M.H.D. Othman, T. Matsuura, A.F. Ismail, M.A. Rahman, Z. Harun, J. Jaafar and M. Nomura, Ceramics International, 44(5), 4538(2017), DOI:10.1016/j.ceramint.2017.12.215

10. G.W.A. Nyakairu, C. Koeberl and H. Kurzweil, Geochemical Journal, 35(4), 245(2001), DOI: 10.2343 /geochemj. 35.245

11. D. Mulyati, Saisa and Irhamni, Research Journal of Pharmaceutical, Biological and Cheemical Science, 7(1), 2222(2016).

12. M.H. Ismayanda, Jurnal Rekayasa Kimia \& Lingkungan, 8(1), 47(2011).

13. R.P. Nugraha and J. O'Sullivan, In: IOP Conference Series: Earth and Environmental Science, ITB, Bandung, (254), 12024(2019), DOI:10.1088/1755-1315/254/1/012024

14. N. Ediz, I. Tatar and A. Aydin, Journal of Ceramic Processing Research, 16(1), 129(2015).

15. I. Hedfi, N. Hamdi, E. Srasra and M.A. Rodríguez, Applied Clay Science, 101, 574 (2014), DOI: 10.1016/j.clay.2014.09.021

16. R. Gopalakrishnan, Rasayan Journal of Chemistry, 9(3), 331(2016).

17. H. H. Murray, Applied Clay Science, 17(5-6), 207(2000), DOI:10.1016/s0169-1317(00)00016-8

18. P. Djomgoue and D. Njopwouo, Journal of Surface Engineered Materials and Advanced Technology, 3(04), 275(2013), DOI:10.4236/jsemat.2013.34037 P

19. S.A. Ahmed, M.A. Tantawy, E.M. Abdallah and M.I. Qassim, International Journal of Advanced Research, 3(3), 1(2015).

20. S. Andrejkovicova, J. Madejova, A. Czimerova, I. Galko, R. Dohrmann and P. Komadel, Geological Carpathica-Bratislava, 57(5), 371(2006)

21. O. Şan and C. Özgür, Journal of the European Ceramic Society, 29(14), 2945(2009), DOI: 10.1016/j.jeurceramsoc.2009.04.013

22. S. Sunardi, U. Irawati and T. Wianto, Jurnal Fisika Flux, 8(1), 59(2011).

23. A.E. Ahmed, S.N. Ahdiri, E.A. Ali, N.M. Khalil and S.A. Salih, Journal of Sebha University-(Pure and Applied Sciences), 15(2), 2016

24. M. Zainuri, Materials Science-Poland, 33(1), 47(2015), DOI: 10.1515/msp-2015-0008

25. P. Sengupta, P.C. Saikia and P.C. Borthakur, journal of Scientific \& Industrial Research, 67, $812(2008)$

26. O.A. Sergievich, E.M. Dyatlova, R.Y. Popov and A.S. Sobachevskii, Engineering Structures and Technologies, 7(2), 97(2015), DOI:10.3846/2029882x.2015.1113893

[RJC-5523/2019] 